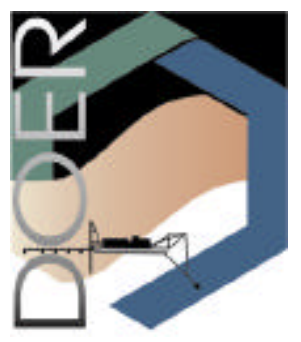

\title{
Innovations in Dredging Technology: Equipment, Operations, and Management
}

PURPOSE: This technical note describes the management approach used to identify currently existing innovative dredging technologies that may be suitable for use by the U.S. Army Corps of Engineers in navigation and dredging activities. A summary of current developments in European dredging and channel maintenance technologies is presented. Also, a Corps invention, the telescoping weir, is introduced as the currently emerging technology with direct application to navigation dredging projects.

BACKGROUND: The Dredging Operations and Environmental Research Program (DOER) has identified six applied research focus areas for development of technology, methodology, and techniques that ensure operational and environmental issues of the U.S. Army Corps of Engineers (Corps) dredging program are addressed adequately and efficiently. In the past, there has been no programmatic or systematic approach to ensure adequate demonstration, evaluation, and reporting of new or innovative dredging technology application. Therefore, the Innovative Dredging Technology Focus Area emphasizes identifying and cataloging innovative dredging operations, processes, or equipment and techniques newly developed by dredging and dredging-related industries worldwide.

INTRODUCTION: In the DOER Program, innovative dredging technology means improved dredging technology that does not require research and development. These technologies are "off the shelf" products. Candidate technologies with the greatest potential will be demonstrated in the field with DOER providing scientific and engineering expertise for monitoring and evaluating the results using the following criteria:

- Corps navigation dredging program needs.

- Positive benefits versus costs.

- High probability of implementation.

- Availability of a co-sponsor.

Candidate technologies must show a high potential for increasing efficiency/productivity of the dredging operations to be considered for demonstration.

FOCUS AREA APPROACH: The following approach is used to identify and demonstrate innovative dredging technologies and management techniques in cooperation with Corps field agencies:

- Identify foreign and domestic government and commercial technologies.

- Evaluate technologies for possible implementation in Corps navigation projects. 
- Determine benefits and costs.

- Demonstrate the equipment and techniques showing potential for adoption.

- Recommend implementation of the most promising technologies for Corps use.

- Transfer Corps-accepted technologies to stakeholders.

PROGRESS TO DATE: Identification of foreign and domestic commercial technologies was completed under contract in April 1999. Problems associated with the maintenance and construction of navigation channels are resolved in the European community by iterative procedures, and progress is influenced according to regulation, funding, economics, government input, technical capability, and public perceptions. The European community has developed solutions for technical and management problems based on local influences. It is possible to identify, implement, and/or integrate these solutions for Corps dredging operations after investigating, documenting, and reviewing them in relation to Corps dredging program needs.

A series of site visits were made to institutions, dredge contractors, port authorities, and project sites in Belgium, United Kingdom, The Netherlands, and Germany. Several types of operations were reviewed and investigated: project management, equipment innovations, and specialty projects designed and built to resolve specific issues associated with waterways. The largest number of innovations identified in these visits is associated with dredge plant and equipment. Europeans have built many of the dredge plants used throughout the world. With the increase of large-scale reclamation and new channel projects, the demand for new dredging equipment has increased. During the construction of this new equipment, component designs and uses have been continuously upgraded to meet the demand.

A final report was prepared under contract with the information gathered from various sources in several countries. The report serves as a comprehensive and convenient reference on the innovative dredging technologies currently available around the world with emphasis on European applications. Of several hundred documents and technologies researched pertaining to innovative technology and procedure, eleven were identified for detailed review as having relevance to present and future long-term needs of the Corps.

DEVELOPMENTS IN EUROPEAN DREDGING AND CHANNEL MAINTENANCE: Highlights of a variety of dredging and channel maintenance innovations within the European communities are discussed in the following paragraphs.

\section{Project Management:}

Project management differs drastically among the different countries visited. In the United Kingdom, port authorities are responsible for all aspects of construction and maintenance of navigational channels. Ports either own dredges or contract out for waterway maintenance, which includes funding, management and implementation. In the Netherlands and Belgium, responsibilities are shared among the ports, government, and private industry. Management and payment vary based on the channel project and government policy, and most of the work is accomplished through contract dredging. 
Port of Rotterdam. The Port of Rotterdam, The Netherlands, has developed a real-time management program for dredge plants working in Rotterdam Harbor. The system includes real-time monitoring of dredge operating systems, production rate, location, draghead settings, and bin operations. It incorporates the latest survey data in an interactive computer-based system. The system is operated from a central office in the Port that allows the Port managers to give real-time directions to dredge operations. The Port enters into 5-year contracts with dredging companies. The Port employs silt traps to increase efficiency and has performed extensive studies to identify contaminated versus clean sediments. Clean sediments are placed back into the North Sea. Contaminated sediments are placed in confined disposal sites. The system is completely integrated with remote links to enable real-time review of dredging operations.

Belgium, Maritime Schelde Department. The Ministry of Flemish Community dredges approximately 80-100 million cubic meters annually from the River Schelde. Most of the material is placed back into the river in several designated sites. To accomplish this massive dredging operation the Ministry enters into maintenance contracts for 7 to 9 years. The contract requires simultaneous deployment of five hopper dredges, three sweep beams, one oil skimmer, one cutterhead suction dredge, one backhoe, and one bucket dredge. Payment is provided through bin measurement and haul distance using an equation developed by the ministry.

To track the operations, the Ministry has developed a dredge information system that provides real-time feedback on key performance parameters to determine how and what the dredge operator is doing and where he is operating. Key performance parameters include location, depth of cut, mixture concentration, and several other components of the operation. Weekly surveys are conducted by the Ministry to determine assignments for the various dredges working for the Ministry at that time. The information system is then employed to determine the compliance with the prescribed program. The management and analyses of dredge operations are real-time and are continuously updated by the Ministry. Current costs are estimated at $\$ 3.50$ to $\$ 4.00 /$ cubic meter (U.S.).

Nearshore Shelf Placement: Rijkswaterstaat, the government agency in charge of navigation channels in The Netherlands, has begun to utilize nearshore placement techniques using conventional bottom-dump dredges to place material in the nearshore for beach nourishment. In 1998, approximately half of all the material placed for beach nourishment was by nearshore placement. Instead of building berms, the Rijkwaterstaat builds shelves of material nearshore, beginning at the 8-m contour. The dredges are equipped with doors that can be opened sequentially, usually bow to stern, and in increments. From the 8-m contour the dredge begins to open its doors and reduces the bottom elevation to approximately $5 \mathrm{~m}$ while reducing the draft of the dredge. As the dredge moves closer to shore, it continues to open more of the bottom doors wider, releasing additional material until it moves to the original 5-m contour. The dredge fills the site until the bottom between the original 8-m and 5-m contour is filled to a depth of $5 \mathrm{~m}$. One placement cycle takes between 6 to 12 minutes. If material must be placed in shallower water, the rainbow technique (a nozzle located in the bow of the vessel used to spray the material up to $50 \mathrm{~m}$ closer to shore) is used. Studies of the placement technique have shown that the sediment migrates shoreward and that it remains within the littoral system. 
Sand/Silt Separation Basin. The Netherlands currently requires sand separation and reclamation for contaminated sediments prior to disposal of the contaminated fraction. Several methods are available including various forms of bar grids for the coarse materials, hydrocyclones for sands and silts, and separation basins such as the one used in De Slufter Confined Disposal Facility (CDF) (see Hopman and McLellan 1999). De Slufter was completed in 1987 to contain contaminated sediments dredged from the Port of Rotterdam. It has a capacity of 100 million cubic meters in its 260-hectare site. In an effort to retain as much site capacity as possible, sand is separated from the contaminated silts on a routine basis. De Slufter managers have continuously looked for innovative approaches to sand reclamation and are currently looking at several different methods including a silting basin and hydrocyclones. A sand separation basin is employed that is sized to the velocity and quantity of material coming into the site. It is a relatively small confined area within De Slufter that expands in the direction of flow to allow for the sand to settle naturally while the fine-grained material remains in suspension and is allowed to flow into De Slufter.

Hydrocyclones have also been employed to separate the sand from the fine-grained materials. According to the managers, the hydrocyclones are responsible for 80 percent of the cost while supplying 20 percent of the sand; the sand separation basin is responsible for 20 percent of the cost while performing 80 percent of the sand separation.

Management of Dredging in the River Waal. Shoaling in the River Waal, The Netherlands, is concentrated along the bendways of the river. Sand waves are common in the river and cause a great deal of problems for navigation. Several nondredging techniques have been used to control shoaling in the bendways: armoring the outside slope to force flow into the interior bank; emergent and submerged groins to train flow to the centerline of channel; and submerged midstream vanes to reduce the spiral flow near the river bottom, reduce scour on the outside bank, and decrease deposition on the inside bank. Approximately 1 million cubic meters of material is dredged from the river, which is estimated to be half to one-third the amount required if only dredging techniques were used.

\section{Dredging Equipment:}

Flexible Spud System. Krupp Fordertechnik has developed a flexible spud system to increase the wave height a cutterhead suction dredge can operate in while working offshore. The spud is not actually flexible, but its cable system is designed in such a way that stresses from the wave-induced motion of the dredge are transferred to the cables and not to the spud. The dredge is allowed to "rock" back and forth on the spud pin allowing it more freedom of motion without putting additional stress on the spud. Working conditions of the dredge are increased up to $2 \mathrm{~m}$ of wave height.

Hopper Dredge Dragarms. Several innovations to hopper dredge dragarms have been developed over the past several years including the overflow water recirculating system, the jet cutting systems, and increased draghead width to improve efficiency. The resulting changes have led to higher efficiencies. The increase in efficiency is so great that smaller hopper dredges, 3,000-cu-m capacity or less, are constructed with only one dragarm. The recirculating system pumps the overflow water from the hopper to the draghead. By eliminating overflow, dredges can operate longer in areas that will not allow overflow and increase efficiency. Some manufactures claim a 20 percent increase in efficiency for dredging silty sand using the recirculating system. The recirculating system does 
require a stand-alone pump and delivery system. Jet cutting is accomplished by injecting highvelocity water into the sediment just before the intake of the draghead. The fluidization accomplishes two objectives: (1) increased cutting action and (2) more efficient entrainment of bottom materials. The jet cutting action more efficiently moves the dredged sediment to the intake while reducing the difference in pressure between the suction head and the ambient water. The reduction in pressure reduces the friction forces between the draghead and the bottom, which reduces the force the dredge must overcome while dredging. With the increased efficiency and reduced friction the dragheads have become wider to take advantage of the jet cutting action.

Punaise. The Punaise is a completely submersible system that can pump free-flowing sand or silt. Primary use in the United States would be to use the Punaise for sand bypassing or beach nourishment projects. The system works best in free-flowing sand with the sand layer around $10 \mathrm{~m}$ in depth. Since the Punaise is submerged, it can work in high sea conditions, which limit surface-piercing dredge plant. Several locations within the United States have been considered for the use of the Punaise including Boca Raton, FL, the Mississippi River, and the mouth of the Columbia River. The Punaise would be extremely effective in locations where relatively small volumes of sand are dredged by a hopper and can be stockpiled offshore. After two or more dredge cycles the Punaise could be used to more efficiently move the sand to the shore.

There are currently three Punaise models, the PN 200, PN 250 and PN 400. All equipment required to mobilize each model can be transported via containers. The PN 200 and PN 250 can also be transferred within containers, while the PN 400 must be transported through conventional shipping. Container shipping reduces mobilization/demobilization costs. The PN 250 and PN 400 have onboard pumps, and the PN 200 requires alternate pumping facilities.

Cable systems and pumping distances currently limit the operation of the Punaise to within 1,000 m of the shoreline discharge point for beach nourishment projects. For remote channel operations, a barge can be utilized to operate the surface equipment. The Punaise is operated remotely by electrical cables. From the remote location, the operator can monitor and manage production rates, temperature, and fuel mixture, as well as ballast and other vital operating parameters. It is estimated that for beach nourishment approximately three to four self-contained buildings will be located on the beach for offices, generators, and fuel. The number of buildings can be reduced if alternate energy sources can be utilized.

Environmental Dredges. Because of years of industrialization, many of the rivers in Europe have become contaminated and require specialty cleanup jobs. To dredge these sediments, several dredges have been developed to make precise cuts, reduce spillage, and decrease turbidity. For example, during the testing phase for the Kettelmeer Project (described in a following paragraph) three different dredges were tested to determine production, spillage, and turbidity generation. The dredges were designed to dredge between 25,000 to 50,000 cu m per week. The three dredges tested included the HAM 291, the WADDENZEE, and the disc cutter VECHT.

All three dredges use a conventional suction dredge platform with different cutting heads. The $H A M$ 291 has a sophisticated dredge head that can articulate and rotate into the face of the cut and provide maximum cut on both swings of the draghead. The pumps and swing speed are computer controlled to obtain the density required for the project. The Ballas Nedam dredge, WADDENZEE, has a suction 
head that resembles a side-looking dustpan head dredge. The orientation of the suction head allows the dredge to remove material in one swing direction only. The VECHT has a rotating cutting basket that can vary the cut depth very accurately and provide exact cutting depths.

All three dredges were able to meet the criteria of limited turbidity and spillage, and most importantly, dredge a 20-to 30-cm thickness of contaminated sediments without entraining additional sediments. The large area of contamination required the accurate dredging capability to ensure that the Ketelmeer project would not need to be oversized.

In addition to "Innovative Dredging Technologies" (Hopman and McLellan 1999), these authors compiled 176 fact sheets containing the following types of information about each technology: technology name, category, description, company or organization, projects completed, information sources, and literature references. The technologies are presented according to subject or country of development or availability.

INNOVATION WITHIN THE CORPS: A number of technologies developed within the Corps are currently undergoing evaluation for potential demonstration under the DOER program. Among the most promising is the telescoping weir, a Corps invention (patent pending) for water management in confined placement sites. From 1986 to 1994, the U.S. Army Engineer Waterways Experiment Station, Vicksburg, MS, and the U.S. Army Engineer District, Norfolk, conceived, designed, constructed, and tested a 1/4-scale model of the first telescoping weir for the Norfolk District (Fowler, Vann, and Woodward 1999). In 1996, the first prototype was constructed and installed in the middle cell of the Craney Island CDF in Norfolk, VA.

The telescoping weir is an innovative structure designed to closely control the water levels and water quality during decantation and drainage of carriage water and rainfall runoff from a CDF (Figure 1). The structure is operated mechanically by lowering and/or raising a cylindrical weir crest to the desired elevation. The weir consists of a set of vertically nested steel cylinders set on end with one cylinder within the other. The bottom cylinder is fixed to a foundation that is anchored to the bottom of the CDF and connected to a discharge pipe (Figure 2). The telescoping weir is set within and attached to a base of a reaction frame that provides support for it and the machinery that controls the telescoping movements of the weir. The weir is raised and lowered by a set of mechanical screw jacks that operate simultaneously either manually or by a solar/batterypowered motor. The upper cylinders are extended in a telescoping manner to position the rim of the top cylinder to any desired elevation above or below the water surface. As the cylinders are lowered

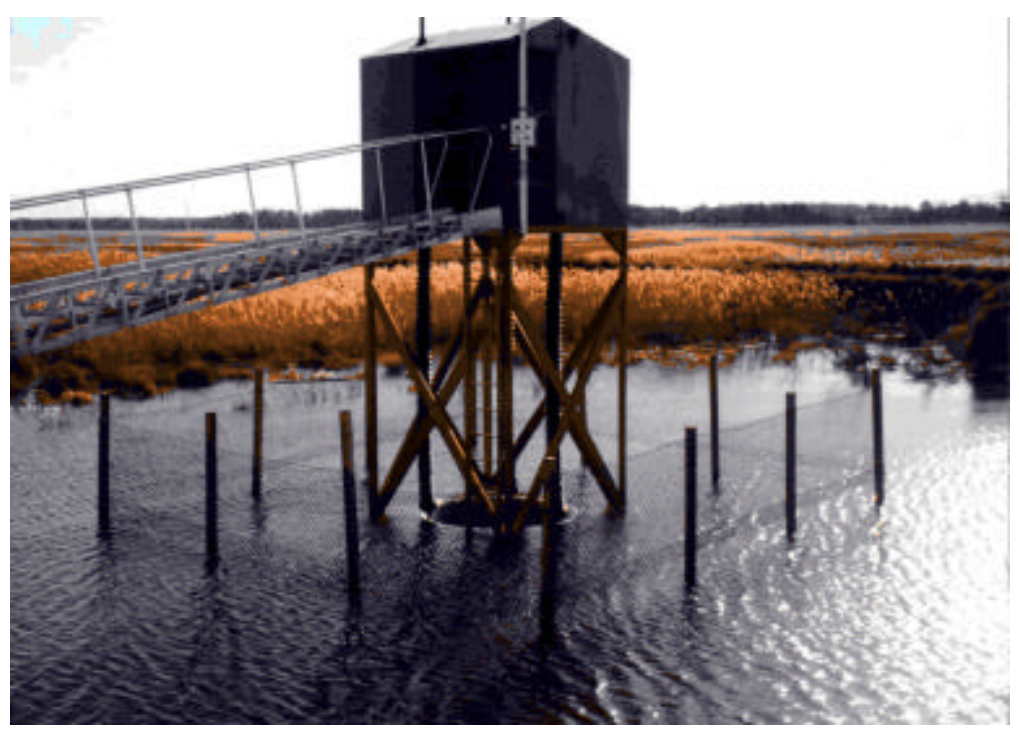

Figure 1. Telescoping weir operating at Craney Island CDF 
below the water surface, the decant water flows over the weir crest into the interior sections, exits through the discharge pipe in the lower section, and returns to the surface water course outside the CDF.

This weir has numerous advantages. The principal advantage is that it provides an infinite elevation adjustment of the weir crest (within the weir design height) and discharge velocities at the touch of a button. The crest of the telescoping weir can be lowered easily to the bottom of the desiccation cracks in the dredged material. This flexibility also provides efficient control of surface runoff, enhancement of the desiccation and the drying processes, and

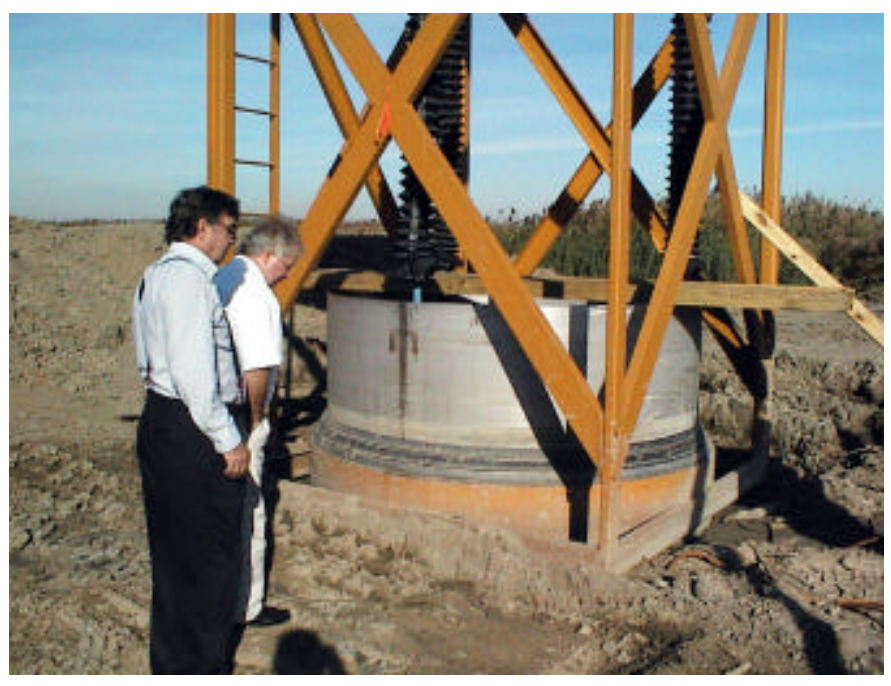

Figure 2. Vertically nested cylinders, screw jacks, and reaction frame, resting on concrete foundation pad some measure of mosquito control. The telescoping weir reduces labor requirements and costs through the elimination of weir board handling, weir board replacement, weir maintenance, and possible weir failure. The weir promotes safer field operations, which is another significant advantage. It can be equipped with a variety of sensors to measure effluent turbidity, temperature, $\mathrm{pH}$, and oxygen levels. Most significantly, this innovative technology offers a new standard in an area of dredging management that has been very difficult to improve upon for many years.

To date, three full-size telescoping weirs have been installed at the Craney Island CDF in Norfolk, VA. The first prototype telescoping weir was installed in April 1996, the second was installed in June 1998, and the third was installed in April 1999. The first weir performed so well, along with two conventional weirs, that the Norfolk District was able to accommodate a record annual placement of 6 million cubic yards of maintenance dredged material. Efficient performance of the telescoping weir eliminated the usual temporary shutdowns of two very large dredging projects. The first two weirs are operational and have required virtually no maintenance to date.

Presently, the Norfolk District is assisting the U.S. Army Engineer District, Mobile, with design and installation of their first telescoping weir. This work should be completed in early 2000. The innovative device has high potential to be used throughout the Corps and other industrial facilities worldwide. Patents for the telescoping weir are pending with the U.S. Patent Agency and foreign countries.

The Innovative Technology Focus Area under DOER is partnering with the Norfolk District to transfer the technology to various Corps users, including the Mobile District. This partnership serves to promote the use of and will aid in the technology transfer to other Corps Districts. In addition to the technical assistance provided under DOER, the U.S. Army Engineer Research and Development Center, Environmental Laboratory, has signed an agreement with the Norfolk District to license the telescoping weir to commercial entities. It is expected that the telescoping weir will be fully licensed to commercial vendors by mid- 2000 . 
Technologies introduced in this technical note are discussed in detail and will be published as ERDC TR-DOER-5 (Hopman and McLellan in preparation).

POINTS OF CONTACT: For additional information contact the authors, Mr. Norman R. Francingues (601-634-3703,francin@wes.army.mil), Mr. Ronald G. Vann (757-441-7057, Ronald. G.Vann@nao02.usace.army.mil), Mr. Thomas D. Woodward (757-441-7125, Thomas.D.Woodward@nao02.usace.army.mil), or the manager of the Dredging Operations and Environmental Research Program, Dr. Robert M. Engler (601-634-3624, englerr@wes.army.mil). This technical note should be cited as follows:

Francingues, N. R., McLellan, T. N., Hopman, R. J., Vann, R. G., and Woodward, T. D. (2000). "Innovations in dredging technology: Equipment, operations, and management," DOER Technical Notes Collection (ERDC TN-DOER-T1), U.S. Army Engineer Research and Development Center, Vicksburg, MS. www.wes.army.mil/el/dots/doer

\section{REFERENCES}

Hopman, R. J., and McLellan, T. N. "Innovative dredging technology,” ERDC TR-DOER-5 (in preparation), prepared by Hartman Consulting Corporation for U.S. Army Engineer Research and Development Center, Vicksburg, MS. www.wes.army.mil/el/dots/doer.

Fowler, J., Vann, R., and Woodward, T. D. (1999). "Telescoping weir for decantation of water from dredged material containment facilities," Proceedings of the Western Dredging Association 19th Technical Conference and 31 st Annual Texas A\&M Dredging Seminar, Louisville, KY, May 16-20, 1999. pp 21-36.

NOTE: The contents of this technical note are not to be used for advertising, publication, or promotional purposes. Citation of trade names does not constitute an official endorsement or approval of the use of such products. 